\title{
Monitoring the prevalence of viable and dead cariogenic bacteria in oral specimens and in vitro biofilms by $\mathrm{qPCR}$ combined with propidium monoazide
}

Ai Yasunaga', Akihiro Yoshida ${ }^{1 *}$, Kazumasa Morikawa², Kenshi Maki², Suguru Nakamura' ${ }^{1}$ Inho Soh', Shuji Awano' and Toshihiro Ansai ${ }^{1}$

\begin{abstract}
Background: Streptococcus mutans and Streptococcus sobrinus are associated with the development of dental caries in humans. However, previous diagnostic systems are unsuitable for monitoring viable cell numbers in oral specimens. Assessing the relationship between the numbers of viable and dead bacterial cells and oral status is important for understanding oral infectious diseases. Propidium monoazide (PMA) has been reported to penetrate dead cells following membrane damage and to cross-link DNA, thereby inhibiting DNA amplification. In the present study, we established an assay for selective analysis of two viable human cariogenic pathogens, S. mutans and S. sobrinus, using PMA combined with real-time PCR (PMA-qPCR).

Results: We designed species-specific primer sets for S. mutans and S. sobrinus, generated standard curves for measuring cell numbers, and evaluated the dynamic range of the assay. To determine the effectiveness of the assay, PMA was added to viable and autoclave-killed cell mixtures. PMA treatment effectively prevented DNA amplification from dead cells. No amplification of DNA from dead cells was observed in these organisms. In addition, we applied this assay to analyze viable cell numbers in oral specimens. A significant correlation was found between the number of viable $S$. mutans cells in saliva and that in plaque among caries-free patients, whereas no correlation was observed between saliva and carious dentin. The total and viable cell numbers in caries-positive saliva were significantly higher than those in caries-free saliva. Finally, we analyzed the usefulness of this assay for in vitro oral biofilm analysis. We applied PMA-qPCR for monitoring viable $S$. mutans cell numbers in vitro in planktonic cells and oral biofilm treated with hydrogen peroxide $\left(\mathrm{H}_{2} \mathrm{O}_{2}\right)$. In planktonic cells, the number of viable cells decreased significantly with increasing $\mathrm{H}_{2} \mathrm{O}_{2}$ concentration, whereas only a small decrease was observed in biofilm cell numbers.
\end{abstract}

Conclusions: PMA-qPCR is potentially useful for quantifying viable cariogenic pathogens in oral specimens and is applicable to oral biofilm experiments. This assay will help to elucidate the relationship between the number of viable cells in oral specimens and the oral status.

Keywords: Dental caries, Dental plaque, Biofilm, Propidium monoazide (PMA), Quantification, aPCR (Real-time PCR), Streptococcus mutans, Streptococcus sobrinus, Viability

\footnotetext{
* Correspondence: akihiro@kyu-dent.ac.jp

${ }^{1}$ Division of Community Oral Health Development, Kyushu Dental University,

2-6-1 Manazuru, Kokurakita-ku Kitakyushu 803-8580, Japan

Full list of author information is available at the end of the article
} 


\section{Background}

Dental caries represents one of the most common infectious diseases afflicting humans [1]. Of the mutans group of streptococci, Streptococcus mutans (serotype $c, e, f$, and $k$ mutans streptococci) and Streptococcus sobrinus (serotype $d$ and $g$ mutans streptococci), which are Gram-positive oral commensal species, are strongly implicated as etiological agents associated with human dental caries. Previous investigations have reported that $S$. sobrinus has a higher acidogenic capacity compared with $S$. mutans, and the prevalence of $S$. sobrinus is more closely associated with high caries activity than is that of $S$. mutans [2,3]. These studies suggest the importance of the diagnoses of infection by these organisms. Previously, several studies have reported methods for diagnosis of these organisms [4,5]. However, DNA-based detection and quantification of specific bacteria cannot distinguish between live and dead bacteria. Bacterial DNA is degraded after the loss of cell viability; thus, the remaining DNA of already dead bacteria can still act as a template DNA for PCR. Consequently, DNA-based detection systems overestimate the cell population. However, we have not differentiated live and dead bacteria within the context of diagnosis of oral infectious diseases, including dental caries. In the present study, we successfully developed and evaluated a discriminative method between live and dead bacteria for the human cariogenic pathogens S. mutans and S. sobrinus using propidium monoazide (PMA). Previously, ethidium monoazide (EMA) was used for discriminating live from dead bacterial cells $[6,7]$. EMA is a DNA/RNA intercalating substance that only enters bacterial cells with compromised cell walls and cell membranes. However, EMA was reported to possibly to penetrate viable cells of some bacterial species, resulting in underestimation of viable bacterial numbers [8-11]. Because PMA is less able to penetrate viable cells, more attention has been paid to PMA as an alternative to EMA [8]. In the present study, we examined the population of live and dead bacteria in oral specimens. The relationships of cell viability with saliva and dental plaque or carious dentin were further analyzed. Finally, we analyzed the cell viability of $S$. mutans assessed by this PMA technique after treatment with hydrogen peroxide $\left(\mathrm{H}_{2} \mathrm{O}_{2}\right)$ and proposed the usefulness of this technique for biofilm experiments. This is the first report to apply the combination of PMA plus real-time PCR (PMA-qPCR) for analysis of the prevalence of live/dead $S$. mutans cells in oral specimens and to reveal the relationship between cell numbers in saliva and cell numbers in dental plaque and/or carious dentin. Additionally, we applied PMAqPCR for monitoring viable $S$. mutans cell numbers in vitro in planktonic cells and biofilm treated with various concentrations of $\mathrm{H}_{2} \mathrm{O}_{2}$ for possible application in biofilm experiments.

\section{Results}

Specificities and sensitivities of the qPCR assay

Fifty-two bacterial strains, including $S$. mutans and $S$. sobrinus strains, were tested using primers designed from genome regions specific for the bacterial strains. Each specific primer pair had broad specificity for the $S$. mutans or S. sobrinus strains (Table 1). Standard curves for linear regression between the threshold cycle $(\mathrm{Ct})$ values and corresponding colony-forming units (CFU) were obtained by 10 -fold serial dilutions of S. mutans and $S$. sobrinus cultures. The regression equations for the standard curves for $S$. mutans and $S$. sobrinus were $\mathrm{Y}=-2.994 \mathrm{X}+35.61\left(R^{2}=0.9914\right)$ and $\mathrm{Y}=-3.230 \mathrm{X}+$ $37.73\left(R^{2}=0.9998\right)$, where $\mathrm{Y}=\mathrm{Ct}, \mathrm{X}=\log _{10} \mathrm{x}$, and $\mathrm{x}=$ CFU, respectively (Additional file 1: Figures S1A and S1B). The dynamic ranges were equivalent to $10^{2}$ to $10^{9} \mathrm{CFU}$ for both $S$. mutans $\left(9.07 \times 10^{-4}\right.$ to $9.07 \times 10^{3} \mu \mathrm{g}$ of chromosomal DNA) and S. sobrinus $\left(2.19 \times 10^{-4}\right.$ to $2.19 \times$ $10^{3} \mu \mathrm{g}$ of chromosomal DNA) per reaction mixture.

\section{Effects of PMA and EMA on cell viability}

We analyzed the effects of various concentrations of PMA on cell viability. The effects of 2.5 and $25 \mu \mathrm{M}$ PMA on the viability of $2.77 \times 10^{6} \mathrm{CFU}$ of S. mutans and $2.85 \times 10^{6} \mathrm{CFU}$ of $S$. sobrinus were almost the same as that of $0 \mu \mathrm{M}$ PMA. After PMA treatment, the bacterial cells were counted. The mean $(n=3)$ values for $S$. mutans and S. sobrinus were $2.6 \times 10^{6} \mathrm{CFU}$ and $2.4 \times$ $10^{6} \mathrm{CFU}$, respectively, at $2.5 \mu \mathrm{M}$ PMA; $2.3 \times 10^{6} \mathrm{CFU}$ and $2.27 \times 10^{6} \mathrm{CFU}$, respectively, at $25 \mu \mathrm{M} \mathrm{PMA}$; and

Table 1 Strains and amplification results for $S$. mutans and S. sobrinus

\begin{tabular}{lccc}
\hline Strain & \multicolumn{2}{c}{ Primers used for amplification } \\
\cline { 2 - 4 } & $\begin{array}{c}\text { S. mutans- } \\
\text { specific }\end{array}$ & $\begin{array}{c}\text { S. sobrinus- } \\
\text { specific }\end{array}$ & Universal \\
\hline S. mutans UA159 & + & - & + \\
S. mutans XC & + & - & + \\
S. mutans MT703R & + & - & + \\
S. mutans MT8148 & + & - & + \\
S. mutans OMZ175 & + & - & + \\
S. mutans NCTC10449 & + & - & + \\
S. mutans Ingbritt & + & - & + \\
S. mutans GS5 & + & + & + \\
S. sobrinus MT8145 & - & + & + \\
S. sobrinus OU8 & - & + & + \\
S. sobrinus OMZ176 & - & + & + \\
S. sobrinus AHT-K & - & & + \\
\hline
\end{tabular}


$6.77 \times 10^{3} \mathrm{CFU}$ and $1.15 \times 10^{6} \mathrm{CFU}$, respectively, at 250 $\mu$ M PMA. Neither 2.5 or $25 \mu$ M PMA treatment had a significant effect on cell viability of either S. mutans or $S$. sobrinus (Student's $t$-test; Figure $1 \mathrm{~A}$ and $1 \mathrm{C}$ ), whereas $2.5 \mu \mathrm{M}$ EMA reduced cell viability of $S$. mutans and $S$. sobrinus by nearly $2.2 \log$ (Figure $1 \mathrm{~B}$ and $1 \mathrm{D}$ ). In addition, PCR was not completely inhibited by treatment of dead cells with $2.5 \mu \mathrm{M}$ PMA (data not shown). Therefore, we used $25 \mu \mathrm{M}$ PMA in this study.

\section{Effect of PMA on defined ratios of viable and heat-killed bacterial suspensions}

To examine the effectiveness of PMA treatment at selectively detecting viable cells in the presence of dead cells, various mixtures comprising viable and heat-killed cells were evaluated by qPCR. An aliquot each of $S$. mutans and S. sobrinus cells was heated at $121^{\circ} \mathrm{C}$ for 15 min in an autoclave. The heat-killed cells were mixed with untreated original culture cells in defined ratios, with viable cells representing $0.01 \%, 0.1 \%, 1 \%$, or $10 \%$ of the total bacteria. In both strains, the signals from 0.01 to $100 \mu \mathrm{g}$ of chromosomal DNA were identical in live cells with and without $25 \mu \mathrm{M}$ PMA-treated heat-killed cells (Figure 2A and 2B).

\section{Spiking S. sobrinus cells with oral specimens}

To examine whether PCR was inhibited in the presence of oral specimens, chromosomal DNA from S. sobrinus-free saliva and plaque specimens was added to $S$. sobrinus cells. The qPCR analysis of $S$. sobrinus was not inhibited by chromosomal DNA from saliva (Figure 3A) or plaque (Figure 3B).

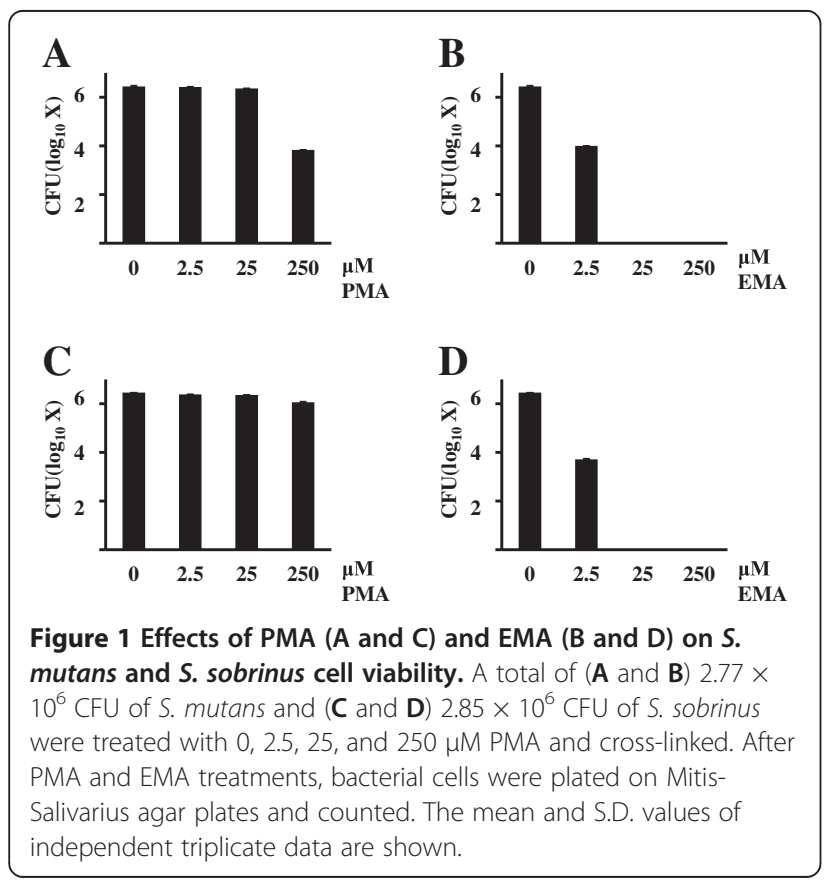

Correlation of viable $S$. mutans cell number assessed by PMA-qPCR and by culture

We compared the $S$. mutans cell number in dental plaque from caries-free patients $(n=24)$ with that from patients with carious dentin $(n=21)$ by $q P C R$ with and without PMA and culture. Positive correlations were observed between the cell number detected by PMA-qPCR and that determined by culture for both caries-free dental plaque (Figure 4A) and carious dentin (Figure 4C). The positive correlations between qPCR and culture are shown in Figure 4B (dental plaque) and 4D (carious dentin). The slopes of the regression equations were lower for qPCR than for PMA-qPCR, indicating that the cell number determined by $\mathrm{qPCR}$ was higher than that determined by PMA-qPCR.

\section{Quantitative discrimination of live/dead cariogenic} bacterial cells in oral specimens

The numbers of S. mutans and S. sobrinus cells in carious dentin and saliva were quantified in patients with dental caries. As shown in Figure 5A, the mean totals of $S$. mutans cells $( \pm$ S.D.) calculated by qPCR without PMA were $1.47 \times 10^{6}\left( \pm 6.88 \times 10^{5}\right)$ per $1 \mathrm{mg}$ dental plaque (wet weight) from caries-free donors $(n=24)$ and $1.48 \times 10^{6}$ $\left( \pm 7.80 \times 10^{5}\right)$ per $1 \mathrm{mg}$ carious dentin (wet weight)

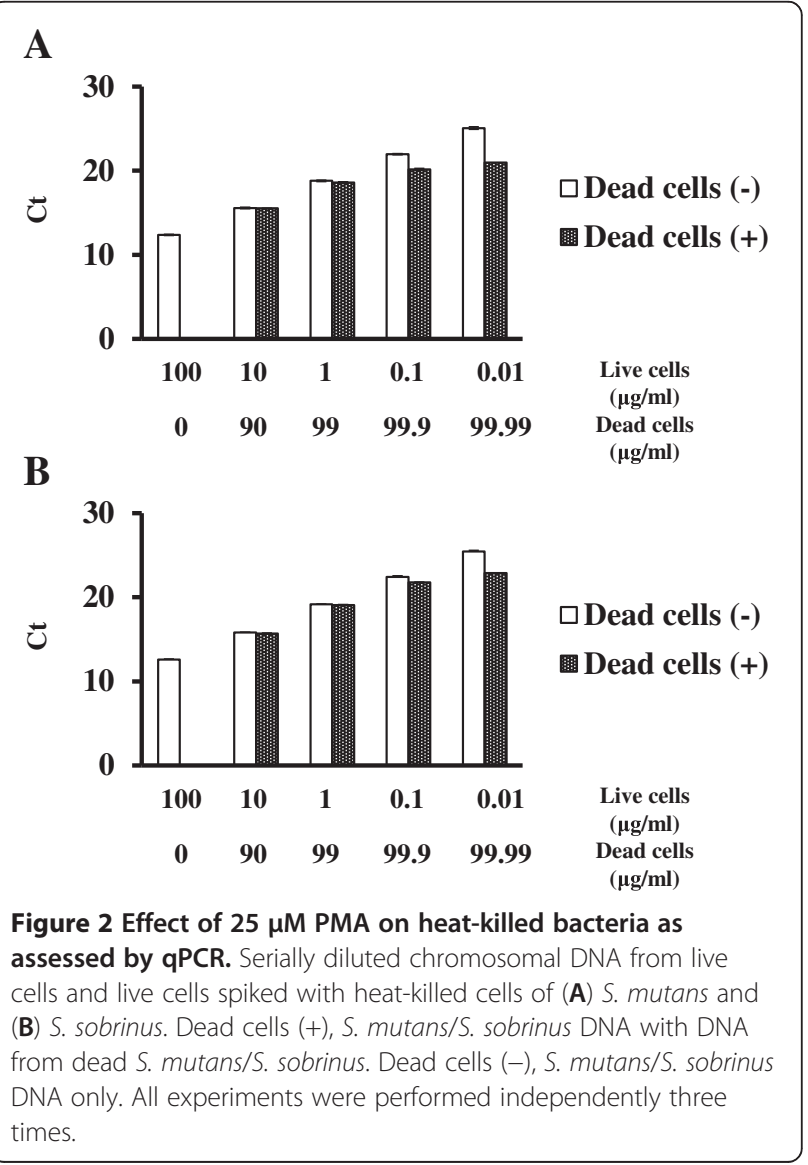




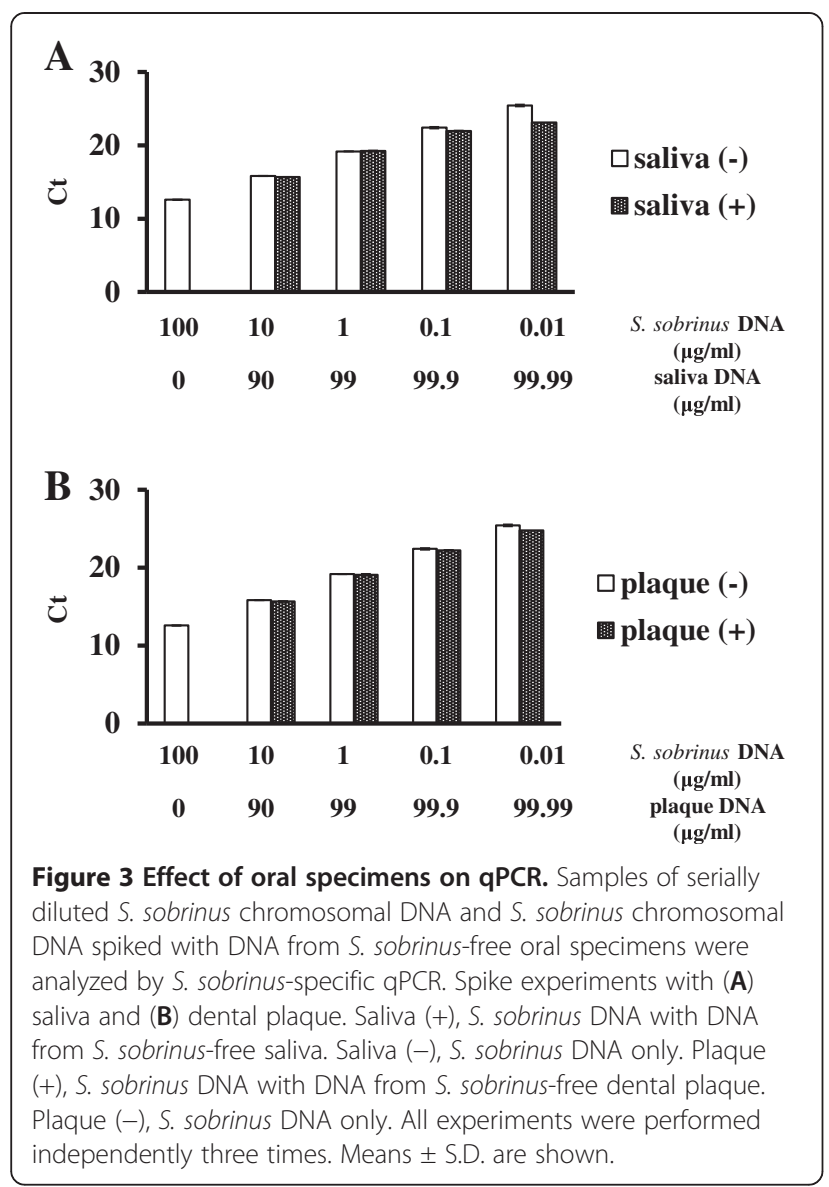

$(\mathrm{n}=21)$; viable cell numbers calculated by qPCR with PMA were $3.98 \times 10^{5}\left( \pm 1.27 \times 10^{5}\right)$ per $1 \mathrm{mg}$ carious dentin (wet weight) and $3.86 \times 10^{5}\left( \pm 1.33 \times 10^{5}\right)$ per $1 \mathrm{mg}$ dental plaque (wet weight), representing $26.9 \%$ and $29.5 \%$ of the total cells, respectively (Figure 5A). There was no significant difference in viable cell number or total cell number between caries dentin and plaque (Mann-Whitney test).

Next, we compared the number of cells in saliva from patients with and without dental caries. The mean totals of $S$. mutans cells $( \pm$ S.D.) calculated by qPCR were $4.24 \times 10^{8}\left( \pm 2.38 \times 10^{8}\right)$ per $1 \mathrm{ml}$ of saliva from patients with dental caries $(\mathrm{n}=21)$ and $1.02 \times 10^{8}\left( \pm 5.07 \times 10^{7}\right)$ per 1 $\mathrm{ml}$ of saliva from caries-free donors $(\mathrm{n}=24)$; viable cell numbers calculated by qPCR with PMA were $1.68 \times 10^{8}$ $\left( \pm 1.06 \times 10^{8}\right)$ per $1 \mathrm{ml}$ of saliva from patients with dental caries $(\mathrm{n}=21)$ and $4.45 \times 10^{7}\left( \pm 3.31 \times 10^{7}\right)$ per $1 \mathrm{ml}$ of saliva from caries-free donors $(n=24)$, representing $39.6 \%$ and $43.6 \%$ of the total cells, respectively (Figure 5B). Total cell number and viable cell number differed significantly between caries-positive and -negative saliva ( $p<0.05$ for each; Mann-Whitney test).

Streptococcus sobrinus was detected in only one patient with dental caries (data not shown). The total numbers of S. sobrinus cells calculated by $\mathrm{qPCR}$ without PMA were
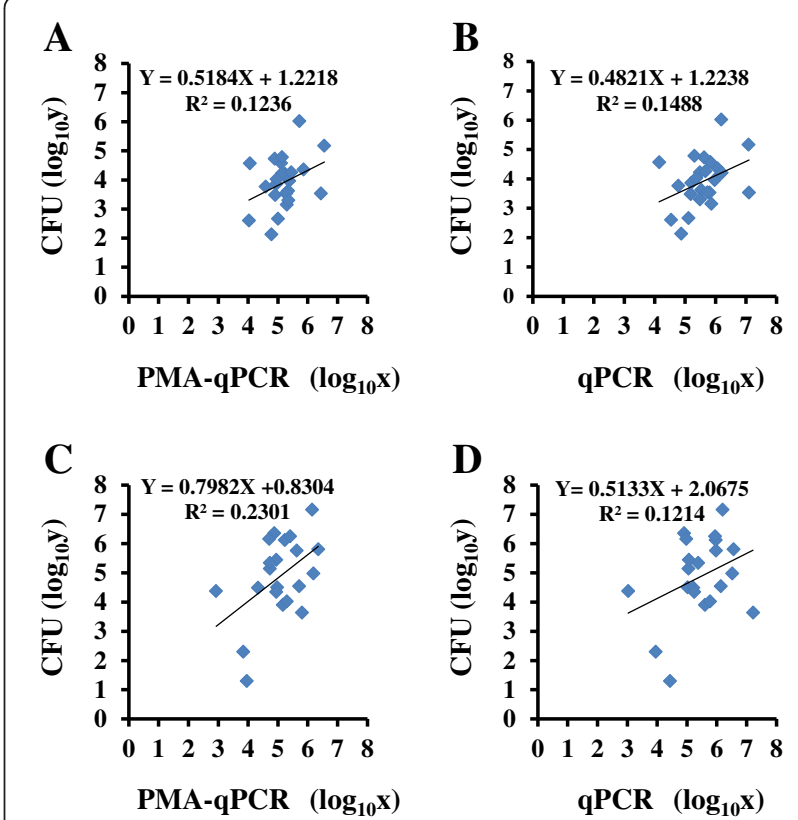

Figure 4 Correlation between number of viable $S$. mutans cells detected by culture and number detected by PMA-qPCR and/or conventional qPCR. (A and B) Dental plaque from caries-free patients $(n=24)$. (B) Carious dentin from patients with dental caries $(n=21)$. All data were calculated three times for CFU, PMA-qPCR, and qPCR, and the mean values were plotted. $X=\log _{10} x$, where $x$ is the cell number calculated by PMA-qPCR (A and $\mathbf{C}$ ) or qPCR (B and $\mathbf{D})$. $Y=\log _{10} y$, where $y$ is CFU.

$8.14 \times 10^{7} \mathrm{CFU}$ per $1 \mathrm{ml}$ of saliva (32.5\% were live cells) and $1.58 \times 10^{9} \mathrm{CFU}$ per $1 \mathrm{mg}$ carious dentin (7.84\% were live cells).

\section{Correlation of viable S. mutans cell number among oral specimens}

The correlations of viable cell number between saliva and caries-free plaque and/or carious dentin were examined. Among caries-free patients, the number of viable $S$. mutans cells in saliva was significantly correlated with the number in plaque $(n=24$, Figure $6 A)$. No correlation was observed between saliva and carious dentin $(n=21$, Figure 6B).

\section{Application of PMA-qPCR for monitoring live bacteria in biofilm and the planktonic phase}

One purpose for the development of this assay was to monitor the viable cell number in biofilm. To evaluate the $S$. mutans cell number in both planktonic and biofilm forms, the cells were exposed to various concentrations of $\mathrm{H}_{2} \mathrm{O}_{2}$. In the planktonic phase, the number of viable $S$. mutans cells in $0.0003 \% \mathrm{H}_{2} \mathrm{O}_{2}$ was only $10.0 \%$ of the number in $\mathrm{H}_{2} \mathrm{O}_{2}$-untreated cells, whereas the number in $0.003 \% \mathrm{H}_{2} \mathrm{O}_{2}$ was $34.7 \%$ of that in $\mathrm{H}_{2} \mathrm{O}_{2}$-untreated cells (Figure 7A). There was a significant 


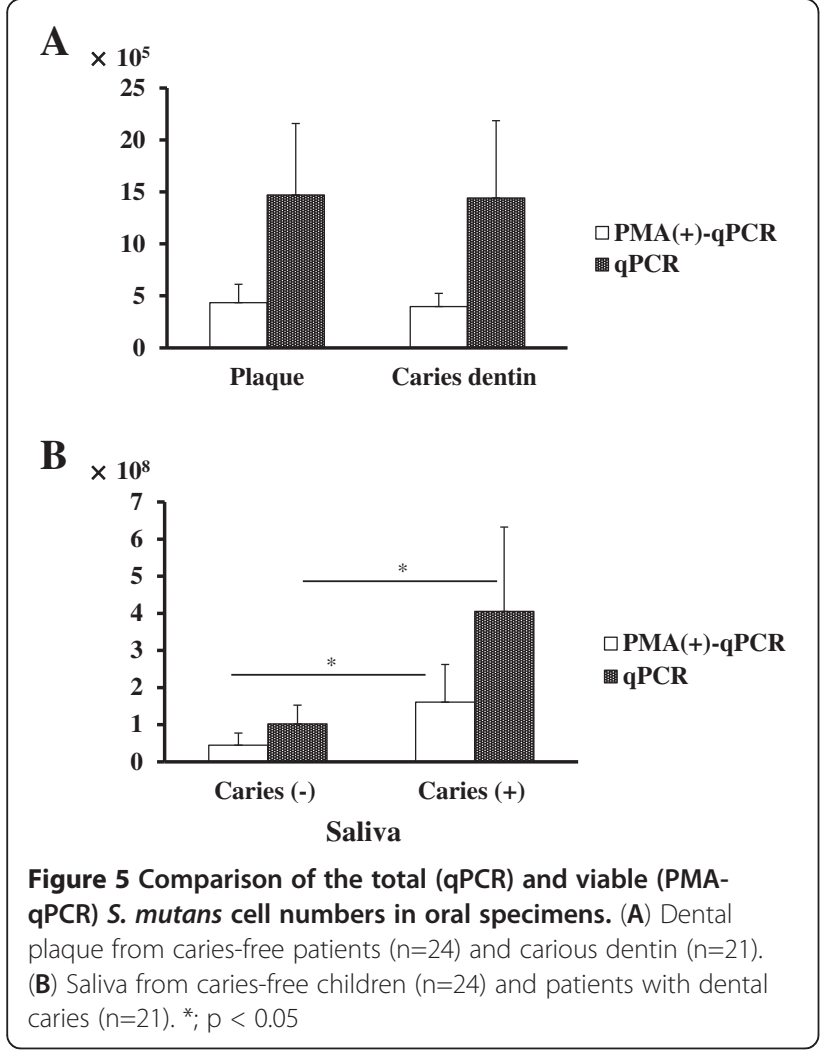

difference in the viable/total cell ratio between $0 \%$ and $0.0003 \% \mathrm{H}_{2} \mathrm{O}_{2}$ (Bonferroni test; $\mathrm{p}<0.05$ ) and between $0 \%$ and $0.003 \% \mathrm{H}_{2} \mathrm{O}_{2}$ (Bonferroni test; $\mathrm{p}<0.01$ ). In biofilm, the number of viable $S$. mutans cells in $0.0003 \%$ $\mathrm{H}_{2} \mathrm{O}_{2}$ was $88.6 \%$ of the number in $\mathrm{H}_{2} \mathrm{O}_{2}$-untreated cells, whereas that in $0.003 \% \mathrm{H}_{2} \mathrm{O}_{2}$ was $58.9 \%$ of that in $\mathrm{H}_{2} \mathrm{O}_{2}$-untreated cells (Figure 7B). There was no significant difference in the viable/total cell ratio between $0 \%$ and $0.0003 \% \mathrm{H}_{2} \mathrm{O}_{2}$ or between $0 \%$ and $0.003 \% \mathrm{H}_{2} \mathrm{O}_{2}$.

\section{Discussion}

Streptococcus mutans and S. sobrinus are considered to be cariogenic pathogens in humans [12]. Various studies have monitored the prevalence of caries-related organisms in oral specimens [13]. However, attempts to differentiate between viable and dead bacteria in oral specimens in relation to dental caries have not been reported. In the present study, we initially developed a quantification method for discriminating live and dead cariogenic bacteria, specifically for S. mutans and S. sobrinus. Previous investigations have reported that EMA has a strong inhibitory effect on the amplification of genomic DNA from viable cells [11], and our study confirmed that EMA itself decreases cell viability. Therefore, all experiments were conducted with PMA, which penetrates a damaged cell membrane and intercalates into DNA, resulting in the inhibition of PCR, in combination with qPCR to
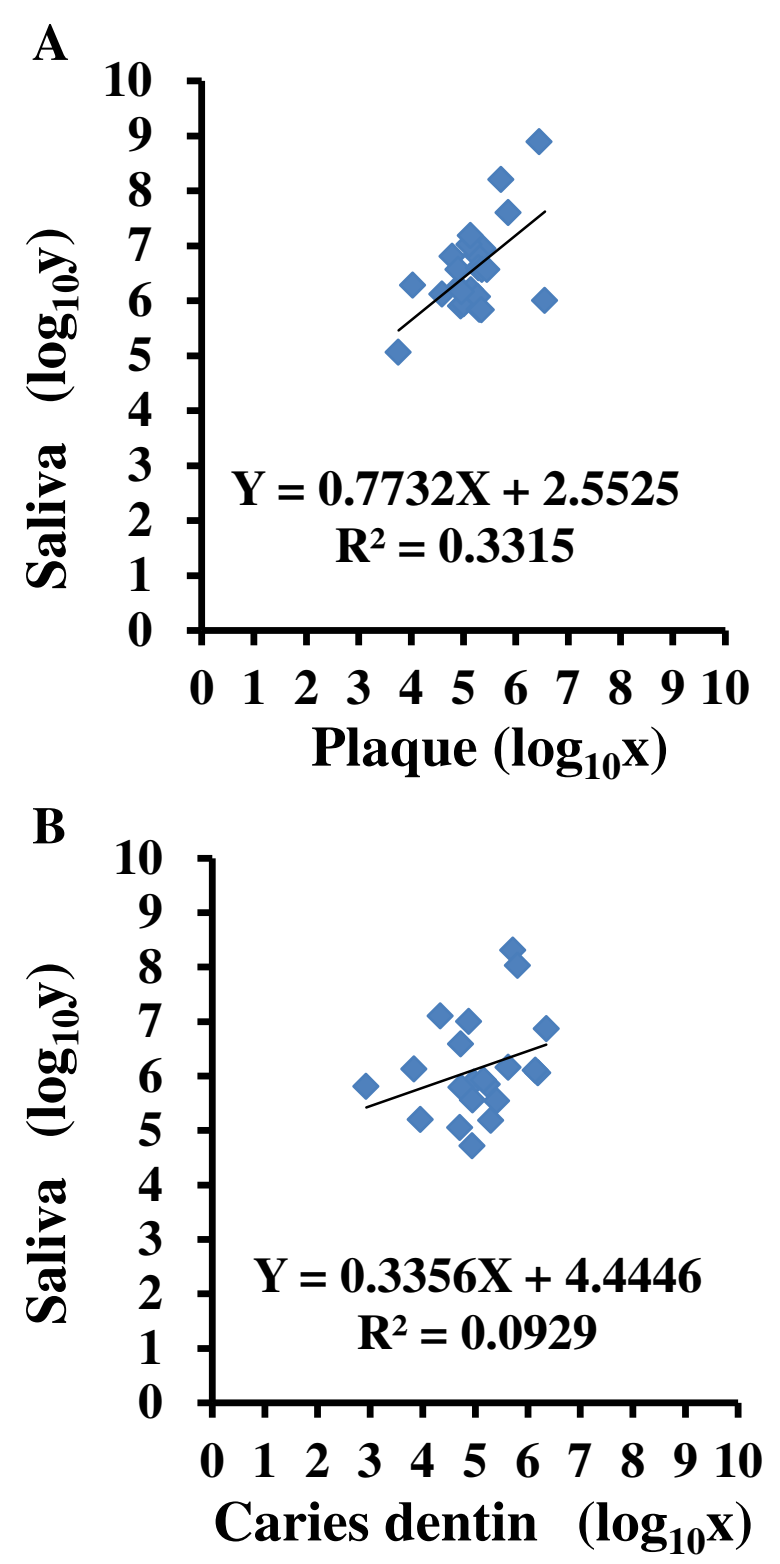

Figure 6 Correlation of viable S. mutans cell number in saliva with viable $S$. mutans cell number in (A) dental plaque from caries-free patients $(n=24)$ and $(B)$ carious dentin $(n=21)$ as assessed by PMA-qPCR. All data were calculated three times, and the mean values were plotted. $X=\log _{10} x$, where $x$ is the viable cell number in dental plaque (A) or carious dentin (B). $Y=\log _{10} y$, where $y$ is the viable cell number in saliva.

quantitatively differentiate between viable and dead cells. We further performed a spiking experiment to evaluate whether this assay was applicable to oral specimens. In general, obtaining oral specimens that do not contain $S$. mutans is challenging, whereas obtaining S. sobrinus-free oral samples is relatively easy. For this reason, we performed PMA-qPCR amplification specific for $S$. sobrinus using S. sobrinus-free saliva and S. sobrinus-free 


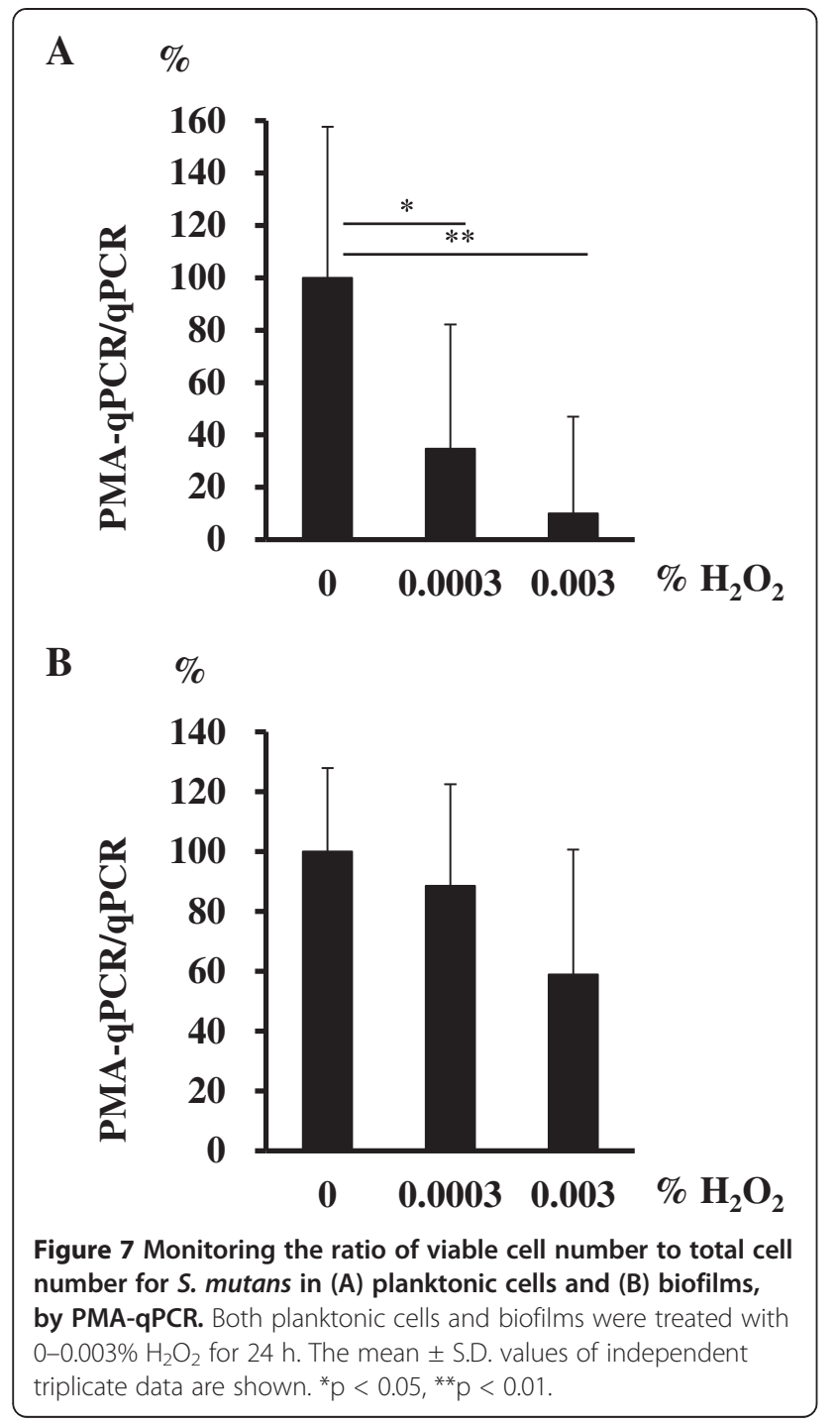

dental plaque as an alternative in the spiking experiment. As shown in Figure 3, neither saliva nor dental plaque inhibited the PCR, indicating that this assay is applicable for measuring cariogenic bacteria in oral specimens.

We next examined the correlation between the numbers of viable $S$. mutans cells in oral specimens as detected by PMA-qPCR and by culture. We found a positive correlation between these quantification methods for both carious dentin and dental plaque. Compared with culture, the number of viable $S$. mutans cells was overestimated by PMA-qPCR. It may be that the culture method usually underestimates the cell number. The cell number determined by conventional qPCR correlated with the cell number determined by culture. Several previous investigations have reported that the cell number determined by qPCR correlated with CFU $[14,15]$. However, compared with PMA-qPCR, conventional qPCR overestimated the cell number to a greater extent in both types of clinical specimens. Therefore, the cell culture count was closer to the number determined by PMA-qPCR than to that determined by conventional qPCR in the present study.

Monitoring viable bacterial cells in oral specimens provides information to help understand oral infectious diseases. When we compared the total and viable cell numbers in carious dentin from patients with dental caries and dental plaque from caries-free children, there was no significant difference between carious dentin and dental plaque in terms of either total number $S$. mutans cells or number of viable cells. We may not be able to simply compare the cell numbers in these specimens because the contents are not identical. Nevertheless, there was no significant difference in the percentage of viable cells between the specimens. However, there was a significant difference in total cell number and viable cell number between saliva from patients with dental caries and saliva from caries-free children. Monitoring of the viable cell number in relation to the total cell number in oral specimens has not previously been performed. To understand the variation in the viable cell number, both the viable and total cell numbers must be determined. To further understand cell viability in relation to dental caries, a greater number of specimens should be analyzed.

When the relationship between the number of viable S. mutans cells in saliva and in dental plaque from caries-free children was analyzed using PMA-qPCR, a positive correlation was found between viable $S$. mutans cells in saliva and in dental plaque. This result was consistent with previous reports [16]. There was no significant correlation between the number of viable $S$. mutans cells in saliva and that in carious dentin from caries patients in the present study. Our data suggest that saliva reflects the number of viable cells in caries-free plaque, but not in carious dentin. Previous studies have found that the microbial biota in the dental plaque of children with severe early-childhood caries was significantly less diverse and less complex than that in caries-free children [17]. Therefore, the viability of cariogenic bacteria in saliva may differ between caries-active and caries-free patients. This possibility should be explored in future studies.

Finally, we evaluated the number of viable of S. mutans cells in the planktonic phase and in biofilm. In the planktonic phase, the ratio of viable cells to total bacteria decreased with an increase in $\mathrm{H}_{2} \mathrm{O}_{2}$ concentration (34.7\% at $0.0003 \% \mathrm{H}_{2} \mathrm{O}_{2}$ and $10.0 \%$ at $0.003 \% \mathrm{H}_{2} \mathrm{O}_{2}$ ). There was a significant difference in the viable/total bacterial ratio between $0 \%$ and 0.0003 and between $0 \%$ and $0.003 \%$ $\mathrm{H}_{2} \mathrm{O}_{2}$. However, the decreases in the viable/total cell ratio in biofilm at these concentrations were smaller $(88.6 \%$ at $0.0003 \% \mathrm{H}_{2} \mathrm{O}_{2}$ and $58.9 \%$ at $0.003 \% \mathrm{H}_{2} \mathrm{O}_{2}$ ), and there was no significant difference between $0 \%$ and 0.0003 or $0.003 \%$ $\mathrm{H}_{2} \mathrm{O}_{2}$. These results suggest that PMA-qPCR is applicable for monitoring the numbers of viable and dead cells in 
biofilm. In biofilm experiments, a live/dead stain is sometimes used to distinguish visually between live and dead bacteria [18]. Although PMA-qPCR is advantageous for quantifying viable cells, it does not provide the visualization obtained with live/dead staining. PMA-qPCR may be a powerful tool for monitoring the number of viable cells in oral biofilms.

\section{Conclusions}

We developed a discriminative quantification method for viable and dead S. mutans and S. sobrinus cells. We evaluated the potential of this assay and applied it to analyze the prevalence of live/dead cariogenic bacteria in oral specimens and to monitor live/dead cells in biofilm experiments. The ability to discrimination between live and dead bacterial cells in biofilm is essential for studying biofilm, and this assay will be helpful for oral biofilm research. Our assay will contribute to elucidating the role of viable bacteria in oral biofilm and saliva in relation to disease activities.

\section{Methods}

\section{Reference strains}

The 52 reference strains used in the present study were S. mutans UA159, S. mutans Xc, S. mutans MT703R, S. mutans MT8148, S. mutans OMZ175, S. mutans NCTC10449, S. mutans Ingbritt, S. mutans GS5, S. sobrinus MT8145, S. sobrinus OU8, S. sobrinus OMZ176, S. sobrinus AHT-K, Streptococcus S. downei Mfe28, S. downei S28, Streptococcus ratti BHT, S. ratti FA1, Streptococcus cricentus HS1, S. cricentus E49, Streptococcus mitis 903, Streptococcus sanguinis ATCC 10556, S. sanguinis ATCC 10557, S. sanguinis OMZ9, Streptococcus gordonii DL1, Streptococcus oralis ATCC 557, Streptococcus salivarius HHT, Streptococcus anginosus FW73, Streptococcus milleri NCTC10707, Lactobacillus rhamnosus JCM1136, L. rhamnosus JCM1561, L. rhamnosus JCM1563, L. rhamnosus JCM8134, L. rhamnosus JCM8135, L. rhamnosus JCM8135, Lactobacillus casei JCM8132, Porphyromonas gingivalis W83, P. gingivalis 33277, Treponema denticola ATCC 35405, Treponema medium ATCC 700293, Treponema vincenti ATCC 35580, Treponema pectinovorum ATCC 33768, Aggregatibacter actinomycetemcomitans $\mathrm{Y} 4, A$. actinomycetemcomitans JCM8577, A. actinomycetemcomitans SUNYaB67, A. actinomycetemcomitans SUNYaB75, Aggregatibacter naeslundii JCM8350, Prevotella loescheii JCM8530, Prevotella denticola JCM8525, Prevotella bivia JCM6331, Prevotella pallens JCM1140, Prevotella veroralis JCM6290, and Prevotella oralis ATCC 33322.

\section{Ethics statement}

All patients were treated in accordance with the Helsinki Declaration regarding the participation of human subjects in medical research. Ethics clearance for the study was obtained from the Ethics Committee of Kyushu
Dental University Hospital (reference number 11-40). The parents of participants were fully informed about the study and signed informed consent forms.

\section{Study subjects and oral specimen sampling}

Twenty-one subjects ranging in age from 3 to 10 years and who had dental caries were included in the caries group (mean age \pm S.D. $=7.86 \pm 0.43$ years; 11 males and 10 females). A healthy (completely caries-free) control group consisted of 24 subjects (ages 3 to 12 years; mean age \pm S.D. $=7.29 \pm 0.56$ years; 13 males and 11 females). The carious dentin was excavated from cavitated lesions. Before excavation of the carious dentin, the plaque on the surfaces of cavitated lesions was swiped. The dental plaque samples from healthy subjects were collected from the buccal or lingual surface of the second primary molar. Collected carious dentin and dental plaque were placed in $200 \mu \mathrm{l}$ of PBS in a sterile $1.5-\mathrm{ml}$ microcentrifuge tube. These samples were washed and placed in PBS solution adjusted to $1 \mathrm{mg}$ per $100 \mu \mathrm{l}$. Saliva was collected from both the caries and healthy control groups. Fifty microliters of saliva was washed with PBS and used for analysis.

\section{Bacterial counting from oral specimens on an agar plate}

Serially diluted carious dentin or dental plaque was plated on a Mitis-Salivarius agar plate (Becton Dickinson, Franklin Lakes, NJ) supplemented with 150 g/l sucrose and $200 \mathrm{U} / \mathrm{l}$ bacitracin for selection of mutans streptococci (MSB agar). Bacterial counting was performed using a magnifying loupe.

\section{Propidium monoazide treatment}

For only viable cell quantification, PMA (3-amino-8-azido5-[3-(diethylmethylammonio)propyl]-6-phenyl dichloride; Wako Pure Chemical, Osaka, Japan) treatment was performed for bacterial cells prior to DNA extraction, as previously described [19]. Briefly, PMA was dissolved in $20 \%$ DMSO to produce a $25-\mathrm{mM}$ stock solution. Following incubation with the dye for $5 \mathrm{~min}$ in the dark, similarly prepared cells were exposed for $5 \mathrm{~min}$ to a 500 -W halogen light placed $15 \mathrm{~cm}$ above $500-\mu \mathrm{l} \mathrm{sam}$ ples in open microcentrifuge tubes on ice. The toxicity

Table 2 Oligonucleotide primers used in this study

\begin{tabular}{llcc}
\hline Primer & \multicolumn{1}{c}{ Sequence $\left(\mathbf{5}^{\prime} \boldsymbol{\rightarrow} \mathbf{3}^{\prime}\right)$} & Locus & Reference \\
\hline Sm F & GTATGCAGGTGAAGAAGC & Sm3-15 & {$[5]$} \\
Sm R & TGGCCACACAATGACCAT & & \\
Ss F & TGGCATTGCCGTAGGAAT & Ss6 & {$[5]$} \\
Ss R & TTGTCGACGGGTTCTAGT & & \\
Universal F & TCCTACGGGAGGCAGCAG & 16S rRNA & {$[21]$} \\
Universal R & GGACTACCAGGGTATCTA & 16S rRNA & \\
\hline
\end{tabular}

$F$ forward primer; $R$ reverse primer. 
of PMA at 2.5-250 $\mu \mathrm{M}$ to S. mutans and S. sobrinus was analyzed at $37^{\circ} \mathrm{C}$. In the present study, $25 \mu \mathrm{M}$ PMA was employed for the analysis. All data presented are from triplicate independent cultures and/or biofilms.

\section{DNA techniques}

Routine molecular biology techniques were performed as described by Sambrook et al. [20]. Chromosomal DNA was isolated from the bacteria using a Puregene DNA isolation kit (Gentra Systems, Minneapolis, MN). Bacterial chromosomal DNA from oral specimens was isolated using MORA-extract (Cosmo Bio, Tokyo, Japan). Next, $150 \mu \mathrm{l}$ of lysis buffer was added to the pellet. The lysed bacteria were transferred to a tube with glass beads and heated at $90^{\circ} \mathrm{C}$ for $10 \mathrm{~min}$. The bacterial mixture was then disrupted using a Mini-Bead Beater (BioSpec Products, Bartlesville, OK) with 0.1-mm-diameter glass beads at 4,800 rpm for $2 \mathrm{~min}$. Thereafter, 200 $\mu \mathrm{l}$ of SDS solution was added and heated at $90^{\circ} \mathrm{C}$ for 10 min. Next, $400 \mu \mathrm{l}$ of phenol solution was added and mixed for $1 \mathrm{~min}$. After centrifugation, the aliquot was subjected to ethanol precipitation and dissolved in $20 \mu \mathrm{l}$ of TE buffer.

\section{qPCR}

To monitor cell numbers, qPCR was performed with S. mutans- and S. sobrinus-specific primers designed using Primer Express 3.0 software (Applied Biosystems, Foster City, CA). The primers specific for S. mutans and S. gordonii are shown in Table 2. A universal primer was used for confirmation of the presence of chromosomal DNA (Table 2). For confirmation of primer specificities, conventional PCR was performed using the following thermocycle: $95^{\circ} \mathrm{C}$ for $5 \mathrm{~min}$, followed by 25 cycles of $95^{\circ} \mathrm{C}$ for $30 \mathrm{~s}, 47^{\circ} \mathrm{C}$ for $30 \mathrm{~s}$, and $72^{\circ} \mathrm{C}$ for $1 \mathrm{~min}$. Quantification of these cells in oral specimens and in vitro biofilm was performed using qPCR with the SYBR green dye to detect the Sm3-15 locus (for S. mutans) and Ss6 locus (for S. sobrinus) amplicons [5]. Bacterial chromosomal DNA was amplified using LightCycler FastStart DNA Master ${ }^{\text {PLUS }}$ SYBR Green I (Roche Diagnostics $\mathrm{GmbH}$, Mannheim, Germany). Each reaction mixture (total $20 \mu \mathrm{l})$ contained $5 \mu \mathrm{l}$ of DNA $(10 \mathrm{ng} / \mu \mathrm{l}), 4 \mu \mathrm{l}$ of $5 \times$ Master Mix, $2 \mu \mathrm{l}$ each of forward and reverse primer (500 nM each), and $9 \mu \mathrm{l}$ of pure water. The mixtures were applied to a LightCycler Capillary (Roche Diagnostics). Amplification and detection of specific products were performed using the LightCycler Carousel-based System (Roche Diagnostics) and the following thermocycle: $95^{\circ} \mathrm{C}$ for $10 \mathrm{~min}$, followed by 45 cycles of $95^{\circ} \mathrm{C}$ for $10 \mathrm{~s}, 58^{\circ} \mathrm{C}$ for $10 \mathrm{~s}$, and $72^{\circ} \mathrm{C}$ for $12 \mathrm{~s}$. Dissociation curves were generated using the following conditions: $95^{\circ} \mathrm{C}$ for $1 \mathrm{~min}, 55^{\circ} \mathrm{C}$ for $1 \mathrm{~min}$, and then an increase in temperature from 55.0 to $95.0^{\circ} \mathrm{C}$ with a heating rate of $0.5^{\circ} \mathrm{C}$ per $10 \mathrm{~s}$. The melting curves with both primer sets showed a single sharp peak (data not shown). DNA concentrations were calculated based on standard curves obtained using 10-fold serial dilutions of bacterial DNA. All data are shown as the mean of triplicate experiments.

\section{Preparation of biofilms and planktonic cells}

To examine $S$. mutans strains for the ability to form biofilm under various $\mathrm{H}_{2} \mathrm{O}_{2}$ concentrations (serially diluted from $0-3 \%$ ), the biofilm assay was performed. Bacterial cells were precultured overnight in chemically defined medium (CDM) supplemented with $0.5 \%$ sucrose, inoculated into $1 \mathrm{ml}$ of $0.5 \%$ sucrose CDM (culture:CDM ratio, $1: 50$ ), and then incubated for $24 \mathrm{~h}$ under anaerobic conditions at $37^{\circ} \mathrm{C}$ in polystyrene 24-well plates (Corning, Inc., Corning, NY) with final $\mathrm{H}_{2} \mathrm{O}_{2}$ concentrations of $0-0.03 \%$ [22]. The viable cell/total cell ratio in $0 \% \mathrm{H}_{2} \mathrm{O}_{2}$ was considered to be $100 \%$.

\section{Statistics}

The Mann-Whitney test and Bonferroni's test were used to determine statistical significance. A difference was deemed significant at $P<0.05$.

\section{Additional file}

Additional file 1: Figure S1. Standard curves for the $\mathrm{qPCR}$ assay were generated by the bacterial cell number and Ct value. (A) S. mutans. (B) S. sobrinus. The mean values of independent triplicate data are shown.

\section{Abbreviations}

EMA: Ethidium monoazide; PMA: Propidium monoazide; qPCR: quantitative polymerase chain reaction.

\section{Authors' contributions}

AYo participated in the study design, wrote the manuscript, and was responsible for the overall coordination of the study. AYa and SN performed the microbiological analysis, DNA manipulation, and PMA-qPCR analysis. KMo and KMa performed clinical examinations and sampling of oral specimens. IS and SA conducted statistical analyses. TA supervised this study.

\section{Acknowledgements}

Support for the present study was provided by Grants-in-Aid (C) 25463257 (A.Y.), (B) 22390403 (T.A.), and (B) (Overseas Academic Research) 24406035 (T.A.) from the Ministry of Education, Culture, Sports, Science and Technology of Japan.

\section{Author details}

${ }^{1}$ Division of Community Oral Health Development, Kyushu Dental University, 2-6-1 Manazuru, Kokurakita-ku Kitakyushu 803-8580, Japan. ²Division of Developmental Stomatognatic Function Science, Kyushu Dental University, Kitakyushu 803-8580, Japan.

Received: 20 December 2012 Accepted: 10 July 2013

Published: 13 July 2013

\section{References}

1. Loesche WJ: Role of Streptococcus mutans in human dental decay. Microbiol Rev 1986, 50:353-380.

2. de-Soet JJ, Toors FA, de-Graaff J: Acidogenesis by oral streptococci at different pH values. Caries Res 1989, 23:14-17. 
3. Fujiwara T, Sasada E, Mima N, Ooshima T: Caries prevalence and salivary mutans streptococci in 0-2-year-old children of Japan. Community Dent Oral Epidemiol 1991, 19:151-154.

4. Yoshida A, Suzuki N, Nakano Y, Kawada M, Oho T, Koga T: Development of a 5 ' nuclease-based real-time PCR assay for quantitative detection of cariogenic dental pathogens Streptococcus mutans and Streptococcus sobrinus. J Clin Microbiol 2003, 41:4438-4441.

5. Nagashima S, Yoshida A, Ansai T, Watari H, Notomi T, Maki K, Takehara T: Rapid detection of the cariogenic pathogens Streptococcus mutans and Streptococcus sobrinus using loop-mediated isothermal amplification. Oral Microbiol Immunol 2007, 22:361-368.

6. Rudi K, Moen B, Drømtorp SM, Holck AL: Use of ethidium monoazide and PCR in combination for quantification of viable and dead cells in complex samples. App/ Environ Microbiol 2005, 71:1018-1024.

7. Flekna G, Stefanic P, Wagner M, Smulders FJ, Mozina SS, Hein I: Insufficient differentiation of live and dead Campylobacter jejuni and Listeria monocytogenes cells by ethidium monoazide (EMA) compromises EMA/ real-time PCR. Res Microbiol 2007, 158:405-412.

8. Nocker A, Cheung CY, Camper AK: Comparison of propidium monoazide with ethidium monoazide for differentiation of live vs dead bacteria by selective removal of DNA from dead cells. J Microbiol Methods 2006, 67:310-320.

9. Nocker A, Sossa-Fernandez P, Burr MD, Camper AK: Use of propidium monoazide for live/dead distinction in microbial ecology. Appl Environ Microbiol 2007, 73:5111-5117.

10. Pan Y, Breidt F Jr: Enumeration of viable Listeria monocytogenes cells by real-time PCR with propidium monoazide and ethidium monoazide in the presence of dead cells. Appl Environ Microbiol 2007 73:8028-8031.

11. Loozen G, Boon N, Pauwels M, Quirynen M, Teughels W: Live/dead realtime polymerase chain reaction to assess new therapies against dental plaque-related pathologies. Mol Oral Microbiol 2011, 26:253-261.

12. Hamada S, Slade HD: Biology, immunology, and cariogenicity of Streptococcus mutans. Microbiol Rev 1980, 44:331-384.

13. Okada M, Soda Y, Hayashi F, Doi T, Suzuki J, Miura K, Kozai K: Longitudinal study of dental caries incidence associated with Streptococcus mutans and Streptococcus sobrinus in pre-school children. J Med Microbio/ 2005, 54:661-665.

14. Klein MI, Scott-Anne KM, Gregoire S, Rosalen PL, Koo H: Molecular approaches for viable bacterial population and transcriptional analyses in a rodent model of dental caries. Mol Oral Microbiol 2012, 27:350-61.

15. Ammann TW, Bostanci N, Belibasakis GN, Thurnheer T: Validation of a quantitative real-time PCR assay and comparison with fluorescence microscopy and selective agar plate counting for species-specific quantification of an in vitro subgingival biofilm model. J Periodontal Res 2013, 48:517-26.

16. Lindquist $B$, Emilson $C G$, Wennerholm K: Relationship between mutans streptococci in saliva and their colonization of the tooth surfaces. Oral Microbiol Immunol 1989, 4:71-76.

17. Li Y, Ge Y, Saxena D, Caufield PW: Genetic profiling of the oral microbiota associated with severe early-childhood caries. J Clin Microbiol 2007, 45:81-87.

18. Boulos L, Prévost M, Barbeau B, Coallier J, Desjardins R: LIVE/DEAD BacLight: application of a new rapid staining method for direct enumeration of viable and total bacteria in drinking water. J Microbiol Methods 1999, 37:77-86

19. Takahashi Y, Yoshida A, Nagayoshi M, Kitamura C, Nishihara T, Awano S, Ansai T: Enumeration of viable Enterococcus faecalis, a predominant apical periodontitis pathogen, using propidium monoazide and quantitative real-time polymerase chain reaction. Microbiol Immunol 2011 55:889-892

20. Sambrook J, Fritsch EF, Maniatis T: Molecular Cloning: a Laboratory Manual. 2nd edition. Cold Spring Harbor, N.Y.: Cold Spring Harbor Laboratory Press; 1989.
21. Nadkarni MA, Martin FE, Jacques NA, Hunter N: Determination of bacterial load by real-time PCR using a broad-range (universal) probe and primers set. Microbiology 2002, 148:257-266.

22. Yoshida A, Kuramitsu HK: Streptococcus mutans biofilm formation: utilization of a gtfB promoter-green fluorescent protein (PgtfB::gfp) construct to monitor development. Microbiology 2002, 148:3385-3394.

doi:10.1186/1471-2180-13-157

Cite this article as: Yasunaga et al:: Monitoring the prevalence of viable and dead cariogenic bacteria in oral specimens and in vitro biofilms by qPCR combined with propidium monoazide. BMC Microbiology 2013 13:157.

\section{Submit your next manuscript to BioMed Central and take full advantage of:}

- Convenient online submission

- Thorough peer review

- No space constraints or color figure charges

- Immediate publication on acceptance

- Inclusion in PubMed, CAS, Scopus and Google Scholar

- Research which is freely available for redistribution 